\title{
Karakterisasi dan Aktivitas Antioksidan Tepung Sagu Baruk (Arenga microcarpha)
}

\section{Elisa Putri Tarigan a*, Lidya Irma Momuat a, Edi Suryanto a}

aJurusan Kimia, FMIPA, Unsrat, Manado

\begin{tabular}{|c|c|}
\hline KATA KUNCI & A B S TR A K \\
\hline $\begin{array}{l}\text { sagu baruk } \\
\text { antioksidan } \\
\text { radikal bebas } \\
\text { fitokimia }\end{array}$ & $\begin{array}{l}\text { Tujuan penelitian ini adalah untuk mempelajari karakteristik kimia tepung } \\
\text { sagu baruk yang mengandung senyawa fitokimia dan mempelajari } \\
\text { aktivitas antioksidan dari ekstrak tepung sagu baruk. Tepung sagu baruk } \\
\text { diekstrak dengan pelarut etanol } 50 \% \text { dengan cara maserasi selama } 24 \\
\text { jam. Setelah itu, tepung sagu diuji proksimat, ekstrak dianalisis } \\
\text { kandungan fitokimia fenolik, flavonoid dan tanin terkondensasi. Pengujian } \\
\text { aktivitas antioksidan menggunakan radikal bebas DPPH dan daya reduksi } \\
\text { dengan spektrofotometer UV/Vis. Hasil penelitian menunjukkan pada } \\
\text { pengujian proksimat bahwa tepung tepung sagu baruk memenuhi syarat } \\
\text { Standar Nasional Indonesia, tetapi berbeda dengan kadar serat kasar. } \\
\text { Total kandungan fenolik dan flavonoid menunjukkan bahwa tepung sagu } \\
\text { akuades (SA) lebih tinggi daripada tepung sagu komersial (TSBK). Hasil } \\
\text { radikal bebas sagu tepung sagu SA lebih tinggi dari TSBK sama halnya } \\
\text { dengan kemampuan daya reduksi SA jauh lebih tinggi dari TSBK. Hasil } \\
\text { penelitian ini menyimpulkan bahwa tepung sagu baruk memiliki } \\
\text { kandungan fitokimia fenolik dan flavonoid yang dapat berpotensi sebagai } \\
\text { antioksidan. }\end{array}$ \\
\hline
\end{tabular}

\section{KEYW O R D}

sago baruk antioxidant free radical phytochemical

\begin{abstract}
A B S T R A C T
Objectives of this research were to study the chemical characteristics of sago baruk flour containing phytochemicals and antioxidant activity of sago baruk flour extract. Sago baruk flour was extracted with $50 \%$ ethanol by maceration for 24 hours. Afterward, sago flour was tested for proximate and the extract was analyzed for phenolic, flavonoids, and condensed tanin. DPPH free radical was used to examine antioxidant activity and spectrophotometry method was used to determine the reduction ability. The result for proximate test showed that sago flour extract meets Indonesian Nasional Standard requirements. Total phenolic and flavonoid contents in the flour extracted with aquadest (SA) were higher than that in commercial flour (TSBK). Free radical scavenging activity of sago flour SA was higher than that of TSBK, as well as the reduction ability of SA that was much higher than of TSBK. It was concluded that sago baruk flour possess phytochemical content of phenolic and flavonoid which were potential as antioxidant.
\end{abstract}

\section{Pendahuluan}

Sulawesi Utara merupakan salah satu daerah yang memiliki kekayaan flora yang dapat dimanfaatkan sebagai tanaman pangan maupun obat. Salah satu tanaman pangan yang dapat digunakan sebagai pangan lokal adalah sejenis tanaman sagu yang disebut dengan sagu baruk. Sagu baruk (Arenga microcarpha Beccari) merupakan tanaman endemik yang dapat memproduksi karbohidrat yang banyak tumbuh di 
daerah Kabupaten Sitaro, Sangihe dan Talaud. Sagu baruk termasuk tanaman perkebunan karena masa pertumbuhan yang panjang, juga sebagai tanaman pangan karena menghasilkan sagu atau karbohidratyang berasal dari empelur batang, serta dimanfaatkan oleh masyarakat lokal sebagai pangan lokal pengganti beras.

Tanaman tersebut membentuk rumpun, sama halnya dengan sagu Metroxylon sp yang membedakannya antara lain, sagu baruk tumbuh pada lahan kering sedangkan sagu Metroxylon sp tumbuh pada lahan yang basah. Sagu baruk, dikenal sebagai tanaman untuk melindungi tanah dan ketersediaan air tanaman sekitarnya. Hal ini ditandai dengan kondisi tanaman sagu baruk tetap hijau pada musim kemarau panjang (Marianus, 2011).

Berbagai penelitian telah dilakukan guna meningkatkan kualitas, nilai jual, serta pemanfaatan sagu dalam indutri pangan. Hal ini dilakukan dengan memperbaiki karakteristik pati maupun memperbaiki metode ekstraksi sagu. Penelitian yang sering dilakukan lebih difokuskan pada kandungan karbohidrat dan pati termodifikasi. Penelitian meningkatkan karakteristik pati sagu telah dilakukan dengan metode modifikasi asetilasi dan cross-lingking dan hidroksipropil (PSHP) yang dilakukan untuk 3 jenis sagu yaitu sagu tuni, sagu ihur dan sagu molat termasuk dalam sagu Metroxylon sp (Teja, 2008; Polnaya, 2009). Penelitian lain, Suryanto dan Papilaya (2013) melaporkan bahwa jenis sagu ihur memiliki kandungan total fenolik dan flavonoid yang tertinggi sedangkan molat memiliki kandungan total tannin terkondensasi tertinggi dari 5 jenis sagu. Sagu ihur juga menunjukkan aktivitas antioksidan paling tinggi daripada molat, tuni, duriitam, kaang dan makanaru.

Berdasarkan penelitian-penelitian yang telah dilakukan di atas, dapat dikatakan bahwa penelitian mengenai sagu umumnya dilakukan untuk perbaikan terhadap metode ekstraksi serta kualitas sagu yang dilihat dari segi karbohidratnya. Namun penelitian mengenai pengaruh proses produksi sagu baruk untuk mendapatkan sagu yang kaya kandungan fitokimia antioksidan sepanjang yang diketahui belum banyak terungkap. Oleh karena itu, penelitian ini akan mempelajari karakteristik dan potensi fitokmia antioksidan dari tepung sagu baruk.

\section{Metode}

\subsection{Material}

Bahan yang digunakan dalam penelitian ini yaitu empulur tanaman sagu baruk diperoleh dari daerah Kabupaten Sangihe. Bahan analisis antara lain: etanol $50 \%$, reagen Folin Ciocalteu, natrium karbonat $2 \%$, aluminium klorida $2 \%$, vanilin $4 \%$, asam klorida pekat, 1,1-difenil-2-pikrilhidrazil, buffer fosfat $\mathrm{pH} 7$, kalium heksasiano besi (III) 1\%, trikloroasetat 10\%, Akuades dan $\mathrm{FeCl}_{3}$ 0,1\%. Alat yang digunakan dalam penelitian ini antara lain: pisau stainless steel, parutan, alat blender, ayakan 60 mesh, oven, alat-alat gelas (tabung reaksi, Erlenmeyer, gelas kimia, gelas arloji, gelas ukur, batang pengaduk), timbangan analitik, mikropipet, vortex, spektrofotometer UV-Vis.

\subsection{Prosedur}

\subsubsection{Proses Pembuatan Tepung Sagu}

Proses produksi tepung sagu yang mengandung antioksidan dilakukan setelah batang dibelah memanjang sehingga bagian dalam terbuka. Bagian teras batang dicacah dan diambil kemudian empelurnya dipotong-potong kecil dengan menggunakan pisau stainless steel dengan ukuran $1 \mathrm{~cm}$. Sebanyak $200 \mathrm{~g}$ empelur sagu baruk diekstraksi dengan $1 \mathrm{~L}$ akuades kemudian dihaluskan dengan blender selama 5 menit dan dilakukan penyaringan menggunakan kain sifon untuk memperoleh filtrat dan ampas. Filtrat selanjutnya didiamkan selama selama 1 jam untuk mendapatkan endapan sagu pertama. Hasil pengendapan berupa sagu basah selanjutnya dilakukan pengeringan dalam oven pada suhu $50^{\circ} \mathrm{C}$ selama 9 jam. Dengan cara yang sama dilakukan ekstraksi pada ampas empelur dengan air, ekstraksi pertama, kedua, ketiga, keempat dan kelima sehingga pada akhir ekstraksi akan diperoleh gabungan endapan pati sagu pertama sampai kelima. Rendemen tepung dihitung berdasarkan berat kering dan hasilnya disimpan dalam kantongkantong plastik sebelum dilakukan karakterisasi kimia, analisis fitokimia dan pengujian aktivitas antioksidan.

\subsubsection{Karakterisasi Kimia dan Fisika Tepung Sagu}

Analisis kimia dan fisika tepung sagu meliputi analisis kadar air, kadar abu, kadar protein, kadar lemak, kadar serat kasar dan karbohidrat dilakukan menurut metode AOAC (1970).

\subsubsection{Ekstraksi Tepung Sagu}

Sebanyak 1g, 2g, 3g, 4g tepung sagu dimasukkan ke dalam tabung reaksi, kemudian diekstraksi dengan $10 \mathrm{~mL}$ pelarut etanol 50\%, selanjutnya divortex dan didiamkan selama 24 jam. Supernantanya ditepatkan kembali menjadi $10 \mathrm{~mL}$ dengan etanol 50\% sehingga diperoleh ekstrak tepung sagu. Selanjutnya ekstrak dianalisis kandungan fitokimia dan pengujian aktivitas antioksidan.

\subsubsection{Penentuan Kandungan Total Fenolik, Flavonoid dan Tannin Terkondensasi}

Kandungan total ekstrak sagu ditentukan dengan menggunakan metode Jeong et al. (2005). Absorbansinya di baca pada $\lambda 750 \mathrm{~nm}$. Hasilnya dinyatakan sebagai ekuivalen asam galat dalam $\mathrm{mg} / \mathrm{L}$ ekstrak. Penentuan kandungan total flavonoid menggunakan metode Meda et al. (2005). Absorbansinya dibaca pada $\lambda 415 \mathrm{~nm}$. Kandungan total flavonoid dinyatakan sebagai ekuivalen kuersetin dalam $\mathrm{mg} / \mathrm{L}$ ekstrak. Kandungan tanin 
terkondensasi sampel ditentukan menurut metode Julkunen-Tinto (1985). Absorbansi dibaca pada $\lambda$ $500 \mathrm{~nm}$ setelah. Kandungan tanin terkondensasi dinyatakan sebagai $\mathrm{mg} / \mathrm{L}$ ekstrak.

\subsubsection{Penentuan Penangkal Radikal Bebas}

Penentuan aktivitas penangkal (scavenger) radikal bebas dari tepung sagu menurut Burda dan Oleszek (2001). Sebanyak 0,5 mL sampel ditambahkan $2 \mathrm{~mL}$ larutan 1,1-difenil-2-pikrilhidrazil (DPPH) $93 \mu \mathrm{M}$ dalam etanol dan divorteks selama 2 menit. Tingkat berkurangnya warna dari larutan menunjukkan efesiensi penangkap radikal. Kemudian diinkubasi selama 30 menit, absorbansi diukur dengan spektrofotometer pada $\lambda 517 \mathrm{~nm}$. Aktivitas penangkap radikal bebas dihitung sebagai persentase berkurangnya warna DPPH dengan menggunakan persamaan:

Aktivitas penangkal radikal bebas (\%)

$$
=\left[1-\frac{\text { absorbansi sampel }}{\text { absorbansi kontrol }}\right] \times 100 \%
$$

\subsubsection{Penentuan Kemampuan Mereduksi Tepung Sagu Baruk}

Sebanyak $1 \mathrm{~mL}$ sampel ditambahkan buffer fosfat $\mathrm{pH} 7$, dan $1 \mathrm{~mL} \mathrm{~K}{ }_{3} \mathrm{Fe}(\mathrm{CN})_{6} 1 \%$ kemudian divorteks. Campuran diinkubasi pada suhu $50{ }^{\circ} \mathrm{C}$ selama 20 menit, kemudian ditambahkan $1 \mathrm{~mL}$ Trikloroasetat (TCA) 10\% divorteks dan disentrifuse 3000 rpm selama 10 menit. Dari campuran tersebut diambil $1 \mathrm{~mL}$ lapisan atas kemudian ditambahkan 1 $\mathrm{ml}$ akuades dan $0,5 \mathrm{~mL} \mathrm{FeCl} 30,1 \%$. Setelah itu dilakukan pengukuran absorbansi dengan menggunakan spektrofotometer pada panjang gelombang $700 \mathrm{~nm}$. Meningkatnya absorban dari campuran tersebut berarti menunjukkan bertambahnya daya reduksi. Kemampuan mereduksi dari sampel dihitung menggunakan persamaan berikut:

Daya reduksi $(\%)=\frac{A-A \min }{A \max -A \min } \times 100 \%$

\section{Hasil dan Pembahasan}

\subsection{Karakterisasi Kimia Tepung Sagu Baruk}

Batang sagu baruk yang digunakan untuk bahan sampel dalam penelitian ini adalah empelur batang sagu segar dengan kadar air 57,18\%. Selanjutnya diekstraksi, diendapkan dan dikeringkan sehingga diperoleh tepung pati sagu yang lolos 65 mesh. Tepung pati sagu baruk yang diperoleh selanjutnya dianalisis proksimat yang meliputi kadar air, abu, protein, lemak, serat kasar dan karbohidrat (by different). Hasil karakterisasi kimia tepung pati sagu baruk disajikan pada Tabel 1.

Tabel 1. Karakterisasi Kimia Tepung pati Sagu baruk

\begin{tabular}{lll}
\hline Komponen & SA & TSBK \\
\hline Kadar Air (\%) & 6,5 & 6,75 \\
\hline
\end{tabular}

\begin{tabular}{lcc}
\hline Kadar Abu (\%) & 0,18 & 0,07 \\
Kadar Protein (\%) & 0,21 & 1,84 \\
Kadar Serat (\%) & 2,25 & 2,13 \\
Kadar Lemak (\%) & 0,26 & 0,42 \\
Karbohidrat (\%) & 90,61 & 88,79 \\
\hline
\end{tabular}

Tabel 1 menunjukkan bahwa kadar air tepung (SA) sebesar $6,5 \%$ relatif tidak berbeda dengan tepung sagu komersial (TSBK) sebesar 6,75\%, tepung sagu yang dihasilkan memenuhi persyaratan Standar Nasional Indonesia (SNI) untuk kadar air tepung sagu yaitu maksimal 13\% (BSN, 2008).

Kadar air berpengaruh pada stabilitas suatu material pada saat disimpan. Apabila suatu bahan memiliki kadar air yang tinggi, maka ketahanan pada saat penyimpanan rendah sehingga mudah rusak saat disimpan (Nielsen, 2003).

Hasil analisis terhadap kadar protein tepung sagu SA dan TSBK diperoleh dapat dilihat pada Tabel 1. Tabel tersebut menunjukkan bahwa kadar protein tepung sagu SA 0,21\% dan TSBK 1,84\%.

Hasil pengukuran kadar serat kasar pada tepung sagu akuades (SA) dan tepung sagu komersial (TSBK) menunjukkan relatif sama. Kadar serat kasar kedua jenis tepung sagu baruk ini tidak memenuhi persyaratan SNI yaitu sebesar 0,5\%. Hal ini mungkin disebabkan oleh faktor proses pembuatan tepung sagu yang dapat mengekstraksi komponen-komponen metabolit sekunder sehingga dapat memberikan kontribusi terhadap peningkatan kadar serat kasar tepung sagu baruk. Hasil pengukuran karbohidrat by different menunjukkan bahwa tepung sagu jenis SA 90,61\% lebih tinggi daripada tepung sagu jenis TSBK 88,79\%.

Penentuan kadar lemak dilakukan dengan metode ekstraksi soxhletasi. Metode ini merupakan metode secara umum untuk penentuan lemak (Horwitz, 2000). Metode ini didasarkan pada pelarut yang dibiarkan kontak dengan cuplikan yang telah dibungkus dengan kertas saring. Hasil analisis terhadap kadar lemak tepung sagu baruk SA dan TSBK adalah 0,26\% dan 0,42\%. Data ini menunjukkan bahwa kadar lemak kedua jenis tepung sagu relatif tidak berbeda.

Kadar abu dalam bahan pangan berhubungan dengan kandungan-kandungan mineral anorganik dari sisa pembakaran pada suhu $550{ }^{\circ} \mathrm{C}$. Sebagian besar bahan pangan terdiri dari bahan organik dan air. Sedangkan sisanya terdiri dari unsur-unsur mineral yang dikenal dengan kadar abu. Hasil pengukuran kadar abu tepung sagu baruk SA dan TSBK adalah 0,18\% dan 0,07\%. Data ini juga relatif tidak tidak berbeda untuk kedua jenis sagu tersebut. Hasil pengujian kadar abu lebih tinggi dengan yang dilaporkan Marianus (2011) yaitu sebesar 0,19\%. Selain itu, hasil pengujian kadar abu masih berada pada kisaran yang dipersaratkan SNI yaitu maksimal 0,5\%. 


\subsection{Penentuan Kandungan Total Fenolik, Flavonoid dan Tanin}

Penentuan kandungan total fenolik, flavonoid dan tanin dilakukan untuk mengetahui potensi antioksidan tepung sagu baruk dengan cara ekstraksi maserasi satu gram tepung sagu baruk dari hasil pelakuan dengan sepuluh milliliter etanol $50 \%$ selama 24 jam. Hasil analisis kedua kandungan fitokimia sampel dapat dilihat pada Gambar 1.

Hasil analisis kandungan total fenolik tepung sagu baruk SA dan TSBK berturut-turut adalah SA $(57,72 \mathrm{mg} / \mathrm{L})$ dan TSBK $(18,41 \mathrm{mg} / \mathrm{L})$. Tingginya kandungan total fenolik tepung sagu SA dapat disebabkan oleh cara ekstraksi tepung sagu SA pada ekstraksi kedua sampai kelima menggunakan pelarut pengekstraksinya adalah air sehingga kandungan fitokimia yang terdapat pada TSBK lebih rendah. Semakin besar intensitas warna yang ditunjukkan maka akan semakin besar pula kandungan fenolik yang terkandung (Julkenen-Titto, 1985).

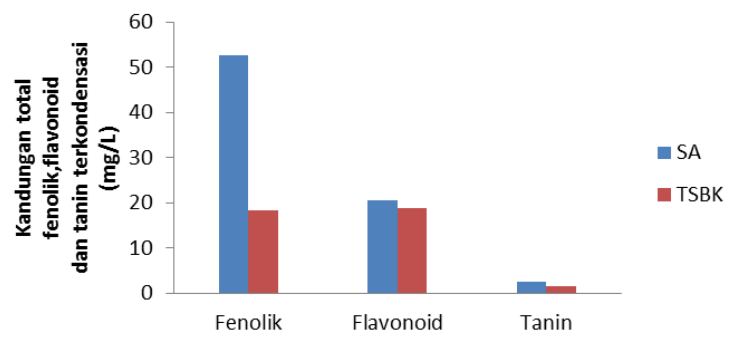

Gambar 1. Kandungan Fitokimia tepung sagu baruk

Dari Gambar 1 kandungan flavonoid tepung sagu SA $(20,637 \mathrm{mg} / \mathrm{L})$ berbeda dengan TSBK yaitu sebesar $18,9 \mathrm{mg} / \mathrm{L}$. Hasil ini menunjukkan sejalan dengan hasil kandungan total fenolik dari kedua jenis sampel tersebut. Kandungan total flavonoid tepung sagu SA dan TSBK lebih rendah dari tepung sagu metroxylon yaitu sebesar $4,81 \mathrm{mg} / \mathrm{L}$ seperti yang dilaporkan oleh Suryanto dan Papilaya (2013). Menurut Larson (1988), komponen fenolik seperti flavonoid yang dikenal sebagai antioksidan primer dari tanaman bersifat polar.

Analisis kandungan flavonoid pada fraksi hasil kromatografi dilakukan dengan menggunakan $\mathrm{AlCl}_{3}$. Penambahan $\mathrm{AlCl}_{3}$ dapat membentuk kompleks asam yang stabil dengan gugus keto C-4 dan gugus hidroksil C-3 atau C-5 pada flavon atau flavonol. Untuk pengukuran flavonoid disertakan dengan senyawa kuersetin yang tersebar luas pada emua pigmen tumbuhan kuning (Robinson, 1995).

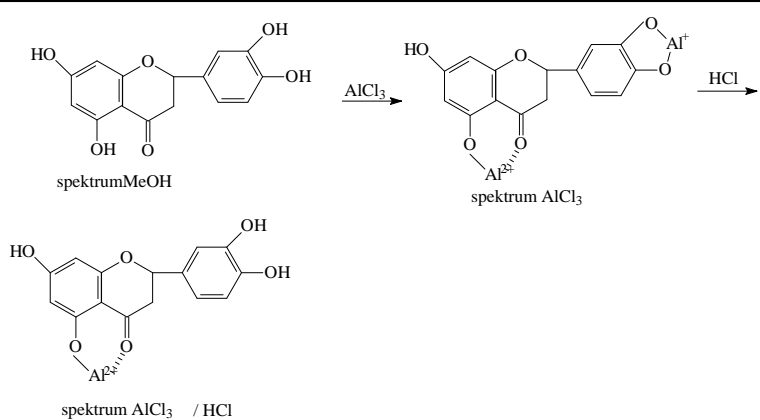

Gambar 2. Reaksi kompleks flavonoid

Hasil analisis kandungan total tanin terkondensasi yang dinyatakan sebagai milligram katekin per kilogram ekstrak dapat dilihat pada Gambar 1. Total tanin terkondensasi tertinggi terdapat pada tepung sagu SA sebesar 2,41 mg/L dan tepung sagu komersial (TSBK) sebesar 1,44 $\mathrm{mg} / \mathrm{L}$. Hasil pengujian kandungan total tanin terkondensasi kedua jenis tepung sagu tersebut lebih rendah dari tepung sagu metroxylon yaitu sebesar 40,19 mg/kg (Suryanto dan Papilaya, 2013). Dari data kandungan total tannin terkondensasi juga memperlihatkan hasil yang sejalan dengan hasil analisis kandungan total fenolik dan flavonoid, dimana tepung sagu SA memiliki kandungan fitokimia yang lebih tinggi daripada TSBK.

\subsection{Penentuan Aktivitas Penangkal Radikal Bebas}

Pengukuran aktivitas antioksidan tepung sagu menggunakan radikal bebas DPPH (1,1-diphenyl-2picrylhydrazyl) sebagai media pengujian aktivitas penangkal radikal bebas. Pengujian aktivitas penangkal radikal bebas tepung sagu dilakukan dengan mereaksikan larutan ekstrak tepung sagu dengan larutan DPPH dan selanjutnya dibaca absorbansinya pada panjang gelombang $517 \mathrm{~nm}$. Penurunan intensitas warna larutan DPPH sebagai akibat terjadi pelepasan atom hidrogen dari senyawa fenolik kepada elektron yang tidak berpasangan yang terdapat pada senyawa DPPH.

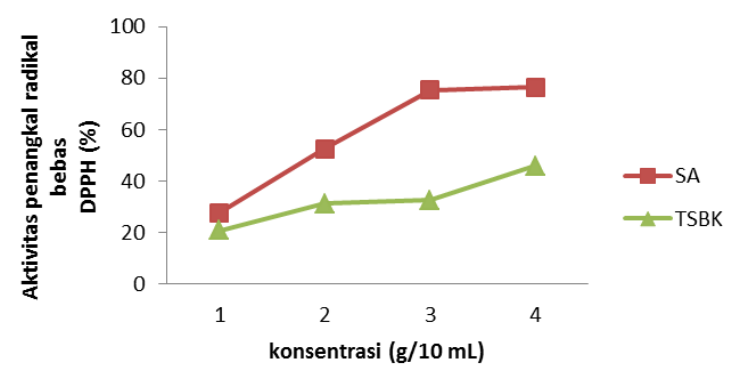

Gambar 3. Aktivitas penangkal radikal bebas DPPH dari kedua jenis tepung sagu baruk pada beberapa konsentrasi

Hasil analisis penangkal radikal bebas terhadap kedua jenis tepung sagu baruk menunjukkan bahwa persentase penangkal radikal 
bebas tepung sagu (SA) memiliki aktivitas antioksidan yang paling tinggi sebesar $76,5 \%$ dan tepung sagu baruk komersial (TSBK) sebesar $46 \%$. Ada kecendrungan bahwa semakin besar konsentrasi tepung sagu jenis SA dan TSBK yang diberikan semakin tinggi aktivitas penangkal radikal bebas DPPH. Karena semakin tinggi konsentrasi yang diberikan maka absorbansinya semakin meningkat. Menurut Lai et al. (2001), aktivitas penangkalan radikal bebas DPPH umumnya naik dengan penambahan ekstrak sampai dengan konsentrasi tertentu, kemudian aktivitas akan turun dengan penambahan konsentrasi yang lebih besar lagi.

Selanjutnya dihitung persamaan garis regresinya, berdasarkan rumus $Y=a X+b$. dari persamaan garis tersebut dihitung $\mathrm{EC}_{50}$, yang merupakan konsentrasi larutan uji radikal bebas DPPH. Persamaan regresi dapat dilihat pada Tabel 2.

Tabel 2. Persamaan Regresi Dan Harga EC50 Larutan Uji

\begin{tabular}{ccc}
\hline $\begin{array}{c}\text { Jenis } \\
\text { larutan uji }\end{array}$ & Persamaan regresi & $\begin{array}{c}\mathrm{EC}_{50}(\mathrm{mg} \\
\text { bahan uji) }\end{array}$ \\
\hline SA & $\mathrm{y}=16,25+16.75 \mathrm{x}$ & 2,015 \\
\hline TSBK & $\mathrm{y}=13,65+7.67 \mathrm{x}$ & 4,739 \\
\hline
\end{tabular}

Tabel 2 memperlihatkan data harga $\mathrm{EC}_{50}$ untuk radikal bebas DPPH dari tepung sagu baruk (SA) dan tepung sagu baruk komersial (TSBK). Nilai EC $_{50}$ dapat digunakan untuk memberikan perkiraan tentang besarnya kemampuan dalam penangkal radikal bebas DPPH dari tepung sagu baruk. Nilai $\mathrm{EC}_{50}$ rendah berarti memiliki kemampuan penangkal radikal bebas yang sangat tinggi. Dari table 3 diperoleh bahwa tepung sagu baruk (SA) memiliki kemampuan menangkal radikal bebas lebih tinggi daripada tepung sagu baruk komersial (TSBK). Dengan kata lain, SA menunjukkan kemampuan menangkal radikal bebas sebesar 50\% daripada tepung sagu baruk komersial (TSBK).

\subsection{Penentuan Kemampuan Mereduksi Tepung Sagu Baruk}

Pengujian aktivitas antioksidan dengan metode kemampuan mereduksi ekstrak tepung sagu baruk terhadap ion komplek $\mathrm{Fe}^{3+} /$ ferrisianida untuk membentuk ion $\mathrm{Fe}^{2+}$. Ion $\mathrm{Fe}^{2+}$ yang terbentuk dapat diamati dengan mengukur pembentukan warna biru Pers's Prussian pada $700 \mathrm{~nm}$. Kenaikan absorban pada $\lambda 700 \mathrm{~nm}$ menunjukkan suatu kenaikan dalam kemampuan mereduksi (Lai et al., 2001). Kemampuan mereduksi tepung sagu baruk (SA) dan tepung sagu baruk komersial (TSBK) sebagai pembanding disajikan pada Gambar 4.

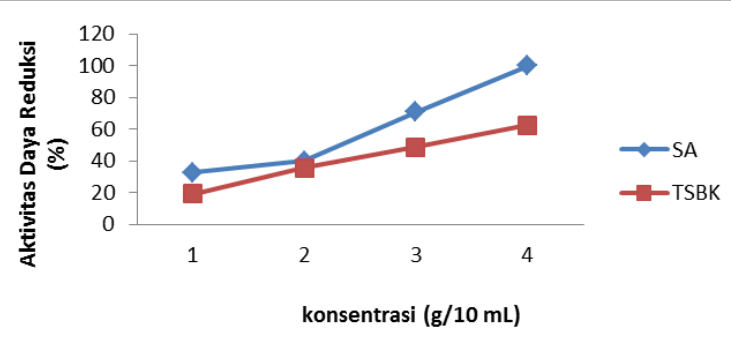

Gambar 4. Kemampuan mereduksi kedua jenis tepung sagu baruk pada beberapa konsentrasi

Gambar 4 memperlihatkan kemampuan mereduksi meningkat dengan bertambahnya konsentrasi ekstrak yang ditunjukkan dengan adanya peningkatan absorbansi pada panjang gelombang $700 \mathrm{~nm}$. Gambar 4 memperlihatkan ada hubungan antara daya reduksi dengan kandungan total fenol dan penangkal radikal DPPH. Tepung sagu baruk (SA) memiliki kemampuan mereduksi lebih tinggi daripada tepung sagu baruk komersial (TSBK), hal ini dapat dilihat bahwa SA pada konsentrasi $4 \mathrm{~g} / 10 \mathrm{~mL}$ memiliki kemampuan mereduksi relatif $100 \%$ sedangkan TSBK sebesar $62,27 \%$. Kemampuan mereduksi dari kedua jenis tepung sagu menunjukkan peningkatan dengan bertambahnya konsentrasi, makin besar konsentrasi ekstrak tepung sagu baruk diberikan semakin kuat kemampuan mereduksinya.

Antioksidan mampu mereduksi radikal bebas yang mempunyai energi potensial yang lebih tinggi (Best, 2004 dalam Rohman dan Riyanto, 2005). Menurut Hart (1983), kemampuan mereduksi berkaitan dengan kemampuan melepaskan atom hidrogen untuk bereaksi dengan radikal bebas sehingga terbentuk radikal antioksidan.

Selanjutnya dihitung persamaan garis regresinya, berdasarkan rumus $\mathrm{Y}=\mathrm{aX}+\mathrm{b}$. dari persamaan garis tersebut dihitung $\mathrm{EC}_{50}$, yang merupakan konsentrasi larutan uji kemampuan daya reduksi. Persamaan regresi dapat dilihat pada Tabel 3.

Tabel 3. Persamaan Regresi Linier Dan Harga EC50 Larutan Uji

\begin{tabular}{ccc}
\hline $\begin{array}{c}\text { Jenis } \\
\text { larutan uji }\end{array}$ & Persamaan regresi & $\begin{array}{c}\mathrm{EC}_{50}(\mathrm{mg} \\
\text { bahan uji) }\end{array}$ \\
\hline $\mathrm{SA}$ & $\mathrm{Y}=2,72+23,274 \mathrm{x}$ & 2,031 \\
\hline $\mathrm{SP}$ & $\mathrm{Y}=5,68+14,272 \mathrm{x}$ & 3,105 \\
\hline
\end{tabular}

Tabel 3 menunjukkan bahwa persamaan regresi dan nilai $\mathrm{EC}_{50}$ dari tepung sagu baruk (SA) lebih rendah daripada tepung sagu komersial (TSBK), ini berarti bahwa SA memiliki kemampuan mereduksi lebih tinggi daripada TSBK.

Pembentukan warna Pearl's Prussian Blue larutan sampel menyebabkan kenaikan pada nilai absorbansi sampel. Makin biru warna yang terbentuk pada sampel makin tinggi niali absorbansinya (Lai et al., 2001). Menunjukkan 
bahwa senyawa antioksidan yang ada dalam tepung sagu hasil perlakuan lebih tinggi dibandingkan tepung sagu baruk yang diolah masyarakat. Dengan kata lain, dari hasil penelitian ini memperlihatkan bahwa tepung sagu SP dan SA memiliki kemampuan sebagai donor elektron $\left(\mathrm{Fe}^{3+}\right.$ menjadi $\mathrm{Fe}^{2+}$ ) dan dapat bereaksi dengan radikal bebas untuk mengubahnya menjadi produk yang sangat stabil serta mengakhiri reaksi rantai radikal. Besarnya kemampuan mereduksi suatu ekstrak antioksidan menunjukkan kemampuannya sebagai donor elektron (Yen dan Chen, 1995).

\section{Kesimpulan}

Dari hasil penelitian ini dapat disimpulkan sebagai berikut:

1. Secara umum karateristik kimia (kadar air, abu, protein, lemak,) tepung sagu baruk memenuhi syarat Standar Nasional Indonesia, berbeda dengan kadar serat kasar yang tidak memenuhi standar SNI.

2. Tepung sagu baruk yang diekstraksi secara sekuensial dengan akuades memiliki kandungan fitokimia fenolik, flavonoid dan tanin terkondensasi serta menunjukkan aktivitas penangkal radikal bebas dan kemampuan mereduksi paling tinggi daripada sagu baruk komersial. Aktivitas antioksidan tepung sagu baruk (SA) meningkat sesuai dengan meningkatnya konsentrasi. Tepung sagu baruk (SA) memiliki aktivitas antioksidan paling besar daripada tepung sagu baruk komersial.

\section{Daftar Pustaka}

Badan Standarisasi Nasional (BSN). 2008. Tepung Sagu. SNI: 01-3729

Burda, S., and W. Oleszek. 2001. Antioxidant and Antiradical Activities of Flavonoids. J. Agric. Food Chem. 49: 2774-2779.

Horwitz, William. 2000. Official Methods of Analysis of AOAC International $17^{\text {th }}$ ed, AOAC International. Gaithersburg.
Jading, A., E. Thetool, P. Payung dan S. Gultom. 2011. Karakteristik Fitokimia Pati sagu Hasil Pengringan secara Fluidisasi Menggunakan Alat Pengering Cross Flow Fluidized Bed Bertenaga Surya dan Biomassa. Reaktor. 13: 155-164.

Jeong, S.M., Kim, S.Y., Kim, D.R., Jo, S.C., Nam, K.C., Ahn, D.U. \& Lee, S.C. 2005. Effect of Heat Treatment on the Antioxidant Activity of Extracts from Citrus Peels. J. Agric. Food Chem. 33: 213217.

Julkenen-Titto, R. 1985. Phenolic Constituents in the Leaves of Northen Willows: Methods for the Analysis of Certain Phenolic. J. Agric. Food Chem. 33: 213-217.

Lai, L-S.Chou, S-T dan Chao, W-W. 2001. Studies on the antioxidative Actibities of Hsian-tsao (Mesona Procumbens Hemsl) Leaf Gum. J. Agric. Food Chem. 49: 963-968.

Marianus. 2011. Tanaman sagu baruk (Arenga microcarpha) sebagai sumber pangan lokal di Kabupaten Kepulauan Sangihe. Laporan Penelitian. Pascasarjana Universitas Brawijaya. Malang.

Nielsen, S. Suzanne. 2003. Food Analysis $3^{\text {rd }}$ ed. Kluwer Academic/Plenum Publishers. New York.

Polnaya, F. J., J. Talahuta, Haryad dan D.W. Marseno. 2009. Karakteristik Tiga Jenis Pati Sagu (Metroxylon sp). Hidroksipropil. J. Agritech. 29:58-65.

Suryanto, E., dan Papilaya, M. 2013. Komposisi Fenolik Dan Aktivitas Antioksidan Dari 6 Jenis Tanaman Sagu (Metroxylon sagu Rottb). Proseding. Seminar Nasional Kimia Terapan Indonesia. Solo.

Teja, W.A., I. Sindi P.,A. Ayucitra, dan L.E.K. Setiawan. 2008. Karakteristik Pati Sagu dengan Metode Modifikasi Asetilasi dan Cross-Linking. J. Teknik Kimia Indonesia. 7 : 836-843.

Yen, G.C dan Chen, H.Y. 1995. Antioxidants Activity of Various Tea Extracts in Relation to Their Antimutagenicity. J. Agric. Food Chem. 43: 383386. 